\title{
Presence of Banks on Social Networks in Bosnia and Herzegovina
}

\author{
Mirela Mabić, Dražena Gašpar, Damir Lucović \\ University of Mostar, Faculty of Economics, Bosnia and Herzegovina
}

\section{Abstract}

Background: Social networks allow real-time interaction that enhances a bank's ability to respond to customers in a timely, intuitive and personalized manner. By using social networks, banks can improve the understanding of their clients and bank's products they need. Also, banks can enhance relations with clients and strengthen their brand through raising client loyalty. Objectives: The paper explores and analyses the current presence of banks in Bosnia and Herzegovina on social networks. Methods/Approach: The paper studies the presence of 24 banks in Bosnia and Herzegovina on social networks and analyses the basic characteristics of profiles/pages of the banks on the most popular social networks. Results: A half of the banks have their profiles/pages on different social networks (mostly on Facebook and YouTube). They use the profiles/pages mainly for content marketing, i.e. for presenting their business operations. Unfortunately, banks do not encourage interaction with clients, except through likes. Conclusions: The analysis does not show that banks have a systematized and planned appearance on social networks. There is a plenty of room for improvement, and it is necessary primarily to address the interaction between clients and banks through social networks.

Keywords: bank; social network; Facebook; YouTube

JEL classification: D83, G21, L86

Paper type: Research article

Received: Nov 11, 2016

Accepted: Aug 03, 2017

Citation: Mabić, M., Gašpar, D., Lucović, D. (2017), "Presence of Banks on Social Networks in Bosnia and Herzegovina", Business Systems Research, Vol. 8, No. 2, pp. 59-70.

DOI: $10.1515 /$ bsrj-2017-0016

\section{Introduction}

The Economic situation, business conditions and rules, interpersonal and interstate relations, as well as other factors that affect business, change at an amazing rate in the last decades. If a company or its management does not follow and adjust to all changes in the market and new situations fast enough, it is bound to fall out of competition for a sufficient market share and for the company to survive and operate at a profit.

The biggest change that has been significantly affecting a company's business is the very emergence of the Internet and all the services that it provides. It is primarily the company management, but also all other employees, that have the task of 
exploring, identifying and mastering all the possibilities that the Internet provides and integrating them into the company's business in a proper, systematic and continuous way. That is the task of all industries, without exception.

The banking industry is specific because this industry significantly depends on its customers, their engagement and commitment to a bank. To enrich the customer experience, banks are therefore faced with the demand for continuous improvement of business, especially the communication aspect of it, by applying new valuable information and communication technologies, the most important today being Web 2.0 technologies, especially social networks.

Social networks are a very powerful channel through which banks can reach out to their customers in order to find out what products their customers want, what decisions they can make to improve relations with customers and what they may be doing that annoys their customers. Further, social networks allow real-time interaction, which enhances a bank's ability to respond to customers in a timely, intuitive and personalized manner - thus enhancing the overall customer experience. Besides, they also allow individuals to learn about a bank's products and services by visiting some of the bank's social networking profiles/pages - while also asking friends within their network for recommendations. The literature generally states that banks can use social networks, among other things, to conduct targeted marketing and reduce their marketing costs, get more detailed information on their customers, foster commitment and loyalty of their customers, get feedback on their products and services, build and strengthen their brand, act proactively to prevent negative connotations associated with the bank, to improve their services for sending money through different online platforms, and to humanize their brand (Chanda and Zaorski, 2013; Eldridge, 2016; Doman, 2015).

Banks can create interactive communication with their clients by using the familiar user-friendly interface of social media (Crowe, 2010). The use of social media platforms offers many potential benefits to financial services organizations and their customers. Social media foster transition from enterprise to social CRM, educating the customer, gaining customer insight, expanding the customer base, achieving customer delight, improving customer service, resolving issues through crowdsourcing, facilitating internal collaboration, and managing risk efficiently (Hazarika and Nag, 2014). The companies like a credit card, debit card, and banks are examples of companies in which the use of social media, especially Facebook and Twitter is growing rapidly (Shao and Shao, 2012).

However, the use of social networks in the banking business should be measured, systematic and methodical. Otherwise, it will not yield quality and valuable results. The four main social media process areas are influencing banking (Veenswyk, 2013):

1. Pre-Approval of Social Content - refers to preparation of the content and defining the date of its publishing on social media.

2. Observing Social Content - refers to monitoring of the activities related to the client complaint, inadequate reply to client requests and fraudulent activities..

3. Investigating Social Content - it is a part of eDiscovey that enables additional support for audits, legal cases, governance and complex analytics of a client or employee.

4. Responding to Social Content - means adequate and formal reply to clients that use social media for communication with bank.

According to Groenfeldt (2014) over the last five to 10 years banks have done enough to keep customers satisfied, but not enough to go further. Banks are usually pretty good on the first move, like internet banking, but then they are slow to fully 
expand upon it because consumer expectations are high, and that is a very big problem for banks. Information technologies rapidly expand and develop, and it is no surprise that clients have their wishes and appetites and want to integrate them into all their activities. It is especially indicative that the generation $Y$ is becoming bank clients who expect to be serviced in the branch, by the Internet, mobile and they are also starting to expect banking services over social networks.

The extent to which Web 2.0 technologies, particularly social networks, are used in the banking business in the world is indicated by the fact that software vendors have offered solutions for management of accounts on social networks - Social Media Dashboard. These control panels (Dashboard) are user-friendly, and their main purpose is to enable monitoring, managing and archiving all of banks' social media conversations from one place. They provide monitoring bank's brand, managing multiple social networks and analyzing social data, scheduling posts and content, archiving social activity, streamline review/approval process for compliance, etc.

Kumar and Devi (2014) emphasize that social media, in the context of financial institutions, empower the following dimensions of business: communication, content and knowing the customers (Chanda and Zaorski, 2013).

Additionally, social networks should be observed in the context of risk reduction (Kumar and Devi, 2014). They claim that financial institutions should use the social graph as one of tool to evaluate credit rating, so social media can impact customer ability to get a loan. According to them, the social graph can identify if potential clients are linked with individuals or communities with a good credit history so the financial institutions can evaluate if the client is trustworthy partner or not. As Eldridge (2016) stated, new financial technology companies, that offer potential cilents access to credit or opening a bank account based on social media data, are emerged.

Further, financial institutions should use posts on social networks to analyze their client location. Sentiment analysis of social media content can be helpful in discovering banks' clients thinking, as well as in foresight of stock market activity for stock movement prediction (Nguyen et al., 2015; Bukovina, 2016a; Bukovina, 2016b; Sprenger et al., 2014a; Sprenger et al., 2014b; Joseph, 2011; Karabulut, 2013; Sul et al., 2017).

King (2010) explored how customer behavior and technology change financial services. He stated that further development of web technologies and innovations in ICT would, not just make doing business easy, but they will significantly change the way of living. It means that new ICT solutions will become "must have," both in business and privately.

Although social media proved to be very powerful communication channel for crisis communication (Aver, 2011; Jin et al., 2014; Pang, et al., 2014; Wendling, et al., 2013), the experiences showed (Black, 2016) that the banks should be very careful in using social media for this purpose. The reason for caution lies in the fact that banks built their relationships with clients on trust so any hint of insecurity could have a negative consequence for the brand. Social media adds speed, transparency, and complexity to crisis communication (Dougherty, 2015). Namely, once started, conversation on social media will not stay limited just to media used by the bank, and it can quickly get out of control. Hence it is important that banks integrate social media into their crisis communication plans as a collaborative tool (Dougherty, 2015).

Mucan and Özeltürkay (2014) explored how Turkish banks use social media for creating competitive advantages. Their study showed a low level of use of social 
media in Turkish banks. The Turkish banks that use social media mostly use Facebook, Twitter, and Linkedln.

Aasheim and Stensønes (2011) explored how Danske Bank deliver traditional financial Service in new channels: Facebook. In this case study, they concluded the usage of social media could have been more strategically because the banks do not manage to use the potential of Facebook fully.

However, it seems that banks in Bosnia and Herzegovina are still not fully aware of the potential of the social networks. They mostly use social networks as an additional marketing channel, instead of as a tool for interactive communication with their customer. Therefore, the aim of the paper is to explore and analyze the current engagement of banks in Bosnia and Herzegovina on social networks. The authors started research with the hypothesis that banks in Bosnia and Herzegovina did not use the social network potential similar to the major banks worldwide. As the authors know, the research of this type has not been conducted in Bosnia and Herzegovina previously. Hereafter is explained the research methodology, the results of research are presented and briefly discussed, and at the end is the conclusion with further guidelines.

\section{Methodology}

A list of banks that currently have a banking license was taken from the Central Bank of Bosnia and Herzegovina's website, which publishes a list of banks operating in Bosnia and Herzegovina. On 30/10/2016 the list included 24 banks (16 in the Federation of Bosnia and Herzegovina ( $\mathrm{F} \mathrm{BiH}$ ) and 8 in the Republic of Srpska (RS)). If a bank operates in both entities (F BiH and RS), the two branches are considered as two banks. Table 1 shows an overview of banks included in the analysis.

Table 1

Banks currently operating in Bosnia and Herzegovina

\begin{tabular}{|c|c|c|c|c|}
\hline & Code & Bank & Head office & Web site $(\mathrm{http} / / \ldots)$ \\
\hline \multirow{16}{*}{ 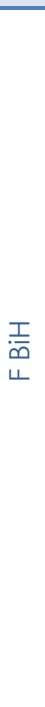 } & $\mathrm{B} 1$ & BOR banka dd Sarajevo & Sarajevo & http://www.borbanka.ba \\
\hline & B2 & Bosna Bank International d.d. Sarajevo & Sarajevo & http://www.bbi.ba \\
\hline & B3 & Addiko Bank & & https://www.addiko-fbih.ba \\
\hline & B4 & $\begin{array}{l}\text { Intesa Sanpaolo Banka d.d. Bosna i } \\
\text { Hercegovina }\end{array}$ & Sarajevo & http://www.intesasanpaolobanka.ba \\
\hline & B5 & $\begin{array}{l}\text { Investiciono-komercijalna banka d.d. } \\
\text { Zenica }\end{array}$ & Zenica & http://www.ikbze.ba/ \\
\hline & B6 & $\begin{array}{l}\text { Komercijalno-investiciona banka d.d. } \\
\text { V.Kladuša }\end{array}$ & $\begin{array}{l}\text { Velika } \\
\text { Kladuša }\end{array}$ & http://www.kib-banka.com.ba \\
\hline & B7 & NLB Banka d.d., Sarajevo & Sarajevo & http://www.nlb.ba \\
\hline & B8 & ProCredit Bank Sarajevo & Sarajevo & http://www.procreditbank.ba \\
\hline & B9 & Raiffeisen Bank d.d. BiH & Sarajevo & http://www.raiffeisenbank.ba \\
\hline & B10 & Razvojna banka Federacije BiH & Sarajevo & http://www.rbfbih.ba/ \\
\hline & B11 & Sberbank BH d.d. Sarajevo & Sarajevo & http://www.sberbank.ba \\
\hline & $\mathrm{B} 12$ & Sparkasse Bank d.d. BiH & Sarajevo & http://www.sparkasse.ba \\
\hline & B13 & UniCredit Bank d.d. Mostar & Mostar & http://www.unicreditbank.ba \\
\hline & B14 & Union banka d.d. Sarajevo & Sarajevo & http://www.unionbank.ba \\
\hline & B15 & Vakufska banka d.d. Sarajevo & Sarajevo & http://www.vakuba.ba \\
\hline & B16 & ZiraatBank BH d.d. & Sarajevo & http://www.ziraatbosnia.com \\
\hline \multirow{8}{*}{$\approx$} & B17 & Addico Bank & Banja Luka & https://www.addiko-rs.ba/ \\
\hline & B18 & Komercijalna banka AD Banja Luka & Banja Luka & http://www.kombank-bl.com \\
\hline & B19 & MF banka a.d. Banja Luka & Banja Luka & http://www.mfbanka.com \\
\hline & B20 & NLB Banka a.d. Banja Luka & Banja Luka & http://www.nlbbl.com \\
\hline & B21 & Nova banka ad Banja Luka & Banja Luka & http://www.novabanka.com \\
\hline & B22 & Pavlović International Bank a.d. & Bijeljina & http://www.pavlovic-banka.com \\
\hline & B23 & Sberbank a.d. Banja Luka & Banja Luka & http://www.sberbankbl.ba \\
\hline & B24 & Unicre dit Bank a.d. Banja Luka & Banja Luka & http://www.unicreditbank-bl.ba \\
\hline
\end{tabular}

Source: Central Bank of Bosnia and Herzegovina (2016) 
Activities of banks on social networks were analyzed through two aspects. It was investigated whether the links to social networks were available on official websites and whether these links were valid and active. If the links were not found on the home page, it was checked whether they were available on the contact page. Availability of the banks' profiles/pages on social networks was also checked directly by searching on the social networks.

Basic characteristics of official profiles/pages of the banks (numerical indicators available on the social network and published content) were analyzed on the most common social networks. The analysis used personal user accounts (profiles) of authors on selected social networks, and it was conducted in October 2016.

\section{Results}

As indicated in the methodology, for the beginning we accessed the official websites of the banks and analyzed if they contained links to social networks, which social networks, where the links were located and the order in which the links are listed. Table 2 shows the results of this analysis.

Table 2

Links to social networks available on official web sites of the banks

\begin{tabular}{|c|c|c|c|c|c|c|c|c|c|c|c|}
\hline & Code & FB & TW & YT & in & G+ & INST & tot & $\begin{array}{c}\% \\
(n=6)\end{array}$ & $\begin{array}{l}\text { link on the } \\
\text { home page }\end{array}$ & $\begin{array}{l}\text { Order on the } \\
\text { web page }\end{array}$ \\
\hline \multirow{16}{*}{ 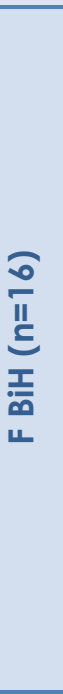 } & B1 & - & $\bullet$ & $\bullet$ & $\bullet$ & & & 4 & 66.7 & + (bottom) & $\mathrm{FB}, \mathrm{TW}$, in, $\mathrm{YT}$ \\
\hline & B2 & - & & & & & & 1 & 16.7 & $+(t o p)$ & $F B$ \\
\hline & B3 & $\bullet ?$ & & $\bullet ?$ & $\bullet ?$ & & - & 1 & 16.7 & + (bottom) & FB, INST, in, YT \\
\hline & B4 & $\bullet$ & & & & & & 1 & 16.7 & + (bottom) & $\mathrm{FB}$ \\
\hline & B5 & & & & & & & & & & \\
\hline & B6 & - & & & & & & 1 & 16.7 & + (bottom) & FB \\
\hline & B7 & $\bullet$ & & - & $\bullet$ & $\bullet$ & & 4 & 66.7 & + (bottom) & in, $Y T, g+, F B$ \\
\hline & B8 & & & & & & & & & & \\
\hline & B9 & $\bullet$ & & - & & & & 2 & 33.3 & + (bottom) & $\mathrm{FB}, \mathrm{YT}$ \\
\hline & B10 & & & & & & & & & & \\
\hline & B11 & - & & - & - & & & 3 & 50 & + (bottom) & $F B, Y T$, in \\
\hline & B12 & - & & - & - & & & 3 & 50 & + (bottom) & $F B$, in, $Y T$ \\
\hline & $\mathrm{B} 13$ & - & & $\bullet$ & & & & 2 & 33.3 & + (bottom) & $\mathrm{FB}, \mathrm{YT}$ \\
\hline & B14 & $\bullet$ & & & $\bullet$ & & & & & + (top) & In, FB \\
\hline & B15 & & & & & & & & & & \\
\hline & B16 & & & & & & & & & & \\
\hline \multirow{8}{*}{ 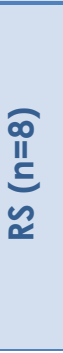 } & B17 & $\bullet ?$ & $\bullet ?$ & & $\bullet ?$ & & - & 1 & 16.7 & + (bottom) & FB, INST, in, YT \\
\hline & $\mathrm{B} 18$ & $\bullet$ & $\bullet$ & & & & & 2 & 33.3 & + (bottom) & FB, TW, RSS \\
\hline & B19 & & & & & & & & & & \\
\hline & B20 & & & & & & & & & & \\
\hline & B21 & & & & & & & & & & \\
\hline & B22 & $\bullet ?$ & $\bullet ?$ & & & $\bullet ?$ & & & & + (bottom) & $\mathrm{FB}, \mathrm{TW}, \mathrm{g}+$ \\
\hline & B23 & $\bullet$ & & - & & & & 2 & 33.3 & + (bottom) & $\mathrm{FB}, \mathrm{YT}$ \\
\hline & B24 & $\bullet$ & & $\bullet$ & - & - & & 4 & 66.7 & + (bottom) & $\mathrm{FB}$, in, $\mathrm{g}+, \mathrm{YT}$ \\
\hline
\end{tabular}

Note: Analysis completed on 29/10/2016; Abbreviations: FB - Facebook, TW - Twitter, YT YouTube, in - Linkedln, G+ - Google plus, INST - Instagram; tot - total; • - social network link exist; ? - social network link exist, but it is broken.

Source: Authors' work

As shown in Table 2, out of 24 analysed banks, eight banks have no links to profiles/pages on social networks in their websites. These should also include the bank Pavlović International Bank a.d. whose website provides links, but clicking them 
reloads the bank's home page or loads the message "Sorry, this page isn't available. The link you followed may be broken, or the page may have been removed.". A total of 15 (62.5\%) banks have integrated social media in their business. If the number of social networks on which the banks have their profiles/pages were analyzed, it is evident that three (18.75\%) banks use four social networks each, two (12.5\%) banks use three social networks each, four (25\%) banks have profiles/pages on two social networks, and five (31.25\%) use only one social network.

On most banks' websites, links to social networks are located on the bottom of the page, for two banks they are found on top, except that for one bank these are not links that open the bank's profiles/pages on social networks but offer the option like on Facebook and follow on Linkedln (Union banka d.d. Sarajevo). According to the order in which these links are arranged on official websites, it is obvious that Facebook dominates in the first place, only in the case of NLB Banka d.d, Sarajevo it is in the last place, and the order of links on social networks is significantly different from other banks.

Although the availability of mobile applications is not the subject of analysis, it was noticed that three banks have the options to download the mobile application from App store or Google play - these are the banks UniCredit Bank d.d. Mostar, Nova banka ad Banja Luka, Unicredit Bank a.d. Banja Luka. This supports the fact that banks want to become closer to their clients and be available to them $24 / 7 / 365$. It should be noted, it is possible that the mobile applications are available for other banks too, but these three banks particularly stood out because these options were literally eye-catching on home pages of their official websites.

Another thing that is observed for the majority of banks is that profiles/pages on social networks load in a new tab, not in the existing; different loading was found only with Sberbank BH d.d. Sarajevo and Sberbank a.d. Banja Luka. It is possible that for most users, this is not an important issue, but loading in new tab greatly facilitates research on the official website - otherwise, every time should again look for the link to the website. Table 3 shows a summary analysis of the results from Table 2.

Table 3

Use of social networks across banks

\begin{tabular}{|c|c|c|c|c|c|c|c|}
\hline & Social network & FB & TW & YT & in & G+ & INST \\
\hline \multirow{2}{*}{$\begin{array}{c}\mathrm{BiH} \\
(n=24)\end{array}$} & $\mathrm{N}$ & 12 & 2 & 8 & 5 & 2 & 2 \\
\hline & $\%$ of row & 50.0 & 8.33 & 33.3 & 20.83 & 8.33 & 8.33 \\
\hline \multirow{3}{*}{$\begin{array}{c}\text { F BiH } \\
(n=16)\end{array}$} & $N$ & 9 & 1 & 6 & 4 & 1 & 1 \\
\hline & $\%$ of row & 56.25 & 6.25 & 37.5 & 25 & 6.25 & 6.25 \\
\hline & $\%$ of column & 75.0 & 50.0 & 75.0 & 80.0 & 50.0 & 50.0 \\
\hline \multirow{3}{*}{$\begin{array}{c}\text { RS } \\
(n=8)\end{array}$} & $N$ & 3 & 1 & 2 & 1 & 1 & 1 \\
\hline & $\%$ of row & 37.5 & 12.5 & 25.0 & 12.5 & 12.5 & 12.5 \\
\hline & $\%$ of column & 25.0 & 50.0 & 25.0 & 20.0 & 50.0 & 50.0 \\
\hline
\end{tabular}

Note: Analysis completed on 29/10/2016; Abbreviations: FB - Facebook, TW - Twitter, YT YouTube, in - Linkedln, G+ - Google plus;

Source: Authors' work

As it was expected, Facebook is the most common social network among the banks. A half of the analyzed banks have a profile/page on that social network; it is slightly more prevalent among the banks operating in $\mathrm{F} \mathrm{BiH}$. The second most common social network is YouTube, again more prevalent among the banks in $\mathrm{F} \mathrm{BiH}$. They are followed by Linkedln, which is used by 5 banks in $\mathrm{BiH}$, while Twitter, Google+ 
and Instagram are in the last place, used by one bank from the Federation $\mathrm{BiH}$ and one bank from RS.

The following is a more detailed analysis of profiles/pages on social networks, especially Facebook pages and YouTube channels because these networks are the most prevalent among the banks.

Table 4 presents the results of the analysis of likes and reviews on banks' Facebook pages, while Table 5 shows which informative components banks' Facebook pages include.

Table 4

Likes and reviews analysis on banks' Facebook pages

\begin{tabular}{|c|c|c|c|c|c|c|c|c|c|c|}
\hline & \multirow[b]{2}{*}{$\begin{array}{l}\frac{0}{0} \\
0 \\
0\end{array}$} & \multicolumn{6}{|c|}{ Likes } & \multicolumn{3}{|c|}{ Reviews } \\
\hline & & $\begin{array}{c}\text { People } \\
\text { Talking } \\
\text { About } \\
\text { This }\end{array}$ & $\begin{array}{l}\text { People } \\
\text { Checked } \\
\text { In Here }\end{array}$ & $\begin{array}{l}\text { Total } \\
\text { Page } \\
\text { Likes }\end{array}$ & $\begin{array}{l}\text { from last } \\
\text { week }\end{array}$ & New & age Likes & $\begin{array}{l}\text { Stars } \\
\left({ }^{*}\right)\end{array}$ & $\begin{array}{c}5 \text { stars } \\
\left(5^{*}\right) / \\
1 \text { star } \\
\left(1^{*}\right)\end{array}$ & Reviews \\
\hline \multirow{9}{*}{ 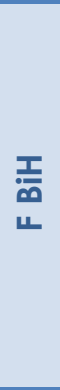 } & $\mathrm{B} 1$ & 3 & 42 & 2082 & $0 \%$ & 1 & $\boldsymbol{\nabla} 50 \%$ & 5.0 & $4 / 0$ & 4 \\
\hline & B2 & 763 & 80 & 26303 & $\Delta 0.3 \%$ & 75 & $\Delta 141.9 \%$ & 4.7 & $101 / 4$ & 117 \\
\hline & B4 & 473 & 29 & 66894 & $\Delta 0.1 \%$ & 62 & $\Delta 72.2 \%$ & 4.0 & $36 / 10$ & 50 \\
\hline & B6 & 43 & 4 & 1656 & $\Delta 0.1 \%$ & 1 & $\nabla 75 \%$ & & & \\
\hline & B7 & 323 & & 4822 & $\Delta 0.3 \%$ & 14 & $\Delta 100 \%$ & & & \\
\hline & B9 & 267 & 177 & 34767 & $\Delta 0.1 \%$ & 40 & $\Delta 48.1 \%$ & 2.9 & $43 / 46$ & 106 \\
\hline & B 11 & 308 & & 16320 & $\Delta 0.3 \%$ & 50 & $\mathbf{\Delta} 38.9 \%$ & & & \\
\hline & B12 & 1933 & 26 & 30678 & А $1.4 \%$ & 411 & $\Delta 165.2 \%$ & 4.3 & $62 / 13$ & 79 \\
\hline & B13 & 1236 & & 37957 & $\Delta 0.3 \%$ & 102 & $\mathbf{\Delta} 70 \%$ & & & \\
\hline \multirow{3}{*}{ 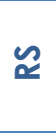 } & B18 & 1211 & & 5944 & $\Delta 3.5 \%$ & 201 & $\Delta 1575 \%$ & & & \\
\hline & B23 & 268 & 1 & 648 & $\Delta 7.3 \%$ & 44 & $\boldsymbol{\nabla} 29 \%$ & 5.0 & $34 / 1$ & 34 \\
\hline & B24 & 145 & & 5917 & $\Delta 0.1 \%$ & 3 & $\nabla 50 \%$ & & & \\
\hline
\end{tabular}

Note: Analysis completed on 29/10/2016

Source: Authors' work

As results in Table 4 show, the number of friends and likes varies widely. The number of friends or people who liked the bank Facebook page ranges from 648 (Sberbank a.d. Banja Luka) to 66894 (Intesa Sanpaolo Banka d.d. Bosna i Hercegovina). Six banks have more than 10000 likes, and only one bank has less than $1 \mathrm{~K}$ likes.

Although it is quite inappropriate to use New Page Likes as a popularity indicator because its variations are unlikely to be based on the bank's activities, it is was noticed significant variations in results - the highest increases are recorded in Sparkasse Bank d.d. BiH, UniCredit Bank d.d. Mostar, Komercijalna banka AD Banja Luka, and the lowest in BOR banka dd Sarajevo and Komercijalno-investiciona banka d.d. Velika Kladuša. In order to use the results to make any specific conclusions and business decisions based on them, the analysis should certainly include bank age (how long the bank operates), the number of its branches, the number of active clients and population in its target market.

Table 5 can provide an instant conclusion on the commitment of the banks to their clients. The frequency of posts is naturally a much better indicator, but information components also indicate the extent to which banks want to become closer to their clients. Almost all of the banks have standard components, but it is necessary to highlight the banks Bosna Bank International d.d. Sarajevo, Raiffeisen Bank d.d. BiH, Sberbank BH d.d. Sarajevo, Sparkasse Bank d.d. BiH and Komercijalna 
banka AD Banja Luka which offer "real" banking options on their Facebook pages, like savings calculator, credit calculator, currency converter, information on credits, savings, cards, etc.

Table 5

Informative components on banks' Facebook pages

\begin{tabular}{|c|c|c|c|c|c|c|c|c|c|c|c|}
\hline & $\frac{0}{0}$ & $\begin{array}{l}\stackrel{0}{\varepsilon} \\
\text { 운 }\end{array}$ & $\begin{array}{l}\text { 亏 } \\
\text { 운 }\end{array}$ & $\begin{array}{l}\frac{0}{0} \\
\frac{c}{\alpha}\end{array}$ & $\underset{\substack{\infty \\
\hdashline}}{\infty}$ & $\stackrel{\mathscr{\psi}}{\stackrel{y}{\Xi}}$ & $\frac{n}{\tilde{L}}$ & 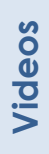 & $\frac{\tilde{\omega}}{\frac{1}{0}}$ & $\sum_{\text {U. }}^{\frac{n}{c}}$ & Additionally \\
\hline \multirow{9}{*}{$\begin{array}{l}\text { I } \\
\text { u }\end{array}$} & B1 & + & + & + & + & + & + & + & & & Invite Your Friend, Welcome \\
\hline & B2 & + & + & + & + & + & + & + & & & $\begin{array}{c}\text { BBI Offices, Financing Calculator, Questions and } \\
\text { Answers, YouTube link, BBI Etiquette, BBI Quiz }\end{array}$ \\
\hline & B4 & + & + & + & + & + & + & + & + & & Mastercard \\
\hline & B6 & + & + & + & & + & + & & + & & \\
\hline & B7 & + & + & + & & + & + & + & & + & Welcome \\
\hline & B9 & + & + & + & + & + & + & + & + & & $\begin{array}{l}\text { Virtual Office, Offices, ATM Network, Credit } \\
\text { Calculator, Infographics, Savings Calculator, } \\
\text { Create your XXL smile, Current Campaign }\end{array}$ \\
\hline & B11 & + & + & + & & + & + & + & + & & Currency Converter, Credits, Savings, Cards \\
\hline & B12 & + & + & + & + & + & + & + & + & + & $\begin{array}{c}\text { Sign up and win, Debit Cards, OsamoSTANite se } \\
\text { (Become APARTMENT independent), Welcome, } \\
\text { PhotoPay, Calculator, Instagram fees }\end{array}$ \\
\hline & B13 & + & + & + & & + & + & + & & + & $\begin{array}{c}\text { Statement of Rights, Welcome, e-educate } \\
\text { yourself, Special Offer }\end{array}$ \\
\hline \multirow{3}{*}{$\approx$} & B18 & + & + & + & & + & + & + & & & $\begin{array}{c}\text { YouTube link, Restricted Use Credits, Cards, Visa } \\
\text { Gift Card, Agricultural Loans }\end{array}$ \\
\hline & B23 & + & + & + & + & + & + & + & & & \\
\hline & B24 & + & + & + & & + & + & + & & + & \\
\hline
\end{tabular}

Note: Analysis completed on 29/10/2016

Source: Authors' work

Through an analysis of the information aspect of Facebook pages, it was established that all the banks have a link to the bank's website and their address published on their of Facebook pages, while only a part of the banks was found to have a map "how to find us" too. It is stated in Facebook pages descriptions that they are banks or financial institutions. Most of the banks use their logo as the profile picture, while cover photo is unstandardized (picture of the bank's headquarters building, logo, something else - handshake as a sign of partnership, etc.).

Pictures and statuses are the most common contents, while videos and announcements of events are slightly less frequent.

The activity of banks on their Facebook pages also varies significantly - every day, at least once in 10 days to the page on which the last post was in 2014.

The activity of customers on banks' Facebook pages is primarily reduced to liking banks' posts. In the comments that customers leave on social networks, there was not a single comment that would indicate an attitude expressed by a customer, one that would represent for the bank a valuable information that could guide future activities of the bank. As for ratings of the Facebook pages, a relatively small number of customers expressed their ratings considering the number of clients who liked the Faceook pages.

Analysis of Youtube channels gives results similar to Facebook. Variations in the characteristics of the channel were significant (Table 6) - 1 subscriber (Bor Banka) to 180 subscribers (Raiffeisen Bank d.d. BiH), posts fairly frequently to once a year or less 
often. Data on characteristics of the channel on YouTube are not available for 6 out of 8 banks, which is in part an indication of how the profiles/pages on social networks are created and maintained.

Table 6

Number of banks' YouTube subscribers and views

\begin{tabular}{ccccccccc}
\hline Code & B1 & B7 & B9 & B11 & B12 & B13 & B23 & B24 \\
\hline $\begin{array}{c}\text { Number of subscribers } \\
\begin{array}{c}\text { Number of views } \\
\text { Number }\end{array}\end{array}$ & 6 & 180 & 19 & 75 & 91 & 4 & 9 \\
\hline
\end{tabular}

Note: Analysis completed on 29/10/2016;

Source: Authors' work

State on Twitter follows the previously described social networks. Certainly, it should be kept in mind that significantly fewer banks use Twitter, but what was found on their channels does not show a particular engagement. The number of followers varies from only a few to several hundred, while the frequency of posts again is not at desirable level - the latest posts on some Twitter channels were 3 months ago. Due to the very low use of other social networks among the studied banks, these were not analyzed in more detail.

\section{Discussion}

As expected, most banks use social networks as a marketing channel, but unfortunately, there is no continuity in that activity. The contents posted by banks do not encourage their clients to any significant response. Facebook is the most common social network among the banks. Some banks have published on YouTube, while Twitter, Google+ and Instagram are rather a little used. There are differences among banks related to the number and quality of information posted on their Facebook page. The number of friends and likes are also different from bank to bank (from 648 friends of Sberbank a.d. Banja Luka to 66894 friends of Intesa Sanpaolo Banka d.d. Bosna i Hercegovina). There are differences in posted content, its format, and frequency of posting. Pictures and statuses are the most common contents, while posts vary from few posts in one day to one post in 10 days. The analysis of YouTube channels gave the similar results. Even a detailed analysis of active profiles/pages of the banks on social networks has not shown that banks take advantage of all the benefits of social networks in the process of communicating with their customers. Namely, based on these results, it can be assumed that not a single bank studies its customers on social networks (what users want, what they may find wrong with the bank, etc.), but use the social networks primarily to present themselves - their services, campaigns, charitable activities, etc. The said assumption is based on the proportion of banks that have profiles/pages on social networks, the frequency of their activities on their profiles/pages, frequency, and methods of interaction of customers with the banks.

The results indicate that there is no continuous plan for posting materials on social networks in terms of both quality and content of published material and in terms of frequency of posting. This only indicates that although a part of the banks follow trends and embrace innovations in the IT sector, they do not address innovations and trends strategically and systematically, which certainly has a significant effect on their results. 


\section{Conclusion}

The results show that there is a lot of room for improvement in the use of social networks in banks in Bosnia and Herzegovina. As it was expected, banks are most present on Facebook and YouTube, while Linkedln and Twitter are significantly less used. Twitter is especially underutilized although this social network is quite popular among business entities in neighbouring countries.

The results of the conducted research confirmed that banks in Bosnia and Herzegovina do not use the potential of social networks similar to the banks worldwide. Banks in Bosnia and Herzegovina have not any systematic and strategic approach to social networks. Management structures in banks should realize as soon as possible that social networks are today very popular and actively used among different age groups not only as a means of communication but also as a means of primary information. Bearing in mind that almost all financial transactions are implemented through financial institutions, it is clear that they have to keep abreast with the times and keep up with trends and shifts in the IT sector and their impact on overall operations. Therefore, it is necessary for all banks to conduct their engagement and "duration" on social networks, as stated, strategically and systematically.

As for further research in this context, it is important to point out several issues. Namely, a presence analysis is not sufficient to make generalized conclusions, especially if the period of observation is very short. Therefore, future research should analyze the activity of banks on social networks during a certain period of time and quantify it through a series of indicators. In addition, it should be explored historically how the profiles/pages on social networks were created - specifically it should be investigated what the reasons of opening (creating) the profiles/pages on social networks were, on whose initiative they were opened, and whether the data of customers who are in active interaction with the bank are analyzed and how. Similarly, attitudes of both bank employees and customers on the importance of social networks in their mutual interaction should also be explored.

It is only a systematic and integrated analysis of results of the recommended studies that would yield clues about the effectiveness of the use of social networks in the banking system. It is up to the banks to take advantage of them as soon as possible, following examples of major global banks.

\section{References}

1. Aasheim, H., Stensønes, I. (2011), "Financial Institutions in Social Media, Deliver Traditional Service in New Channels; A Case Study of Danske Bank", master's thesis, Copenhagen Business School, available at: http://studenttheses.cbs.dk/bitstream/handle/10417/2961/hege aasheim og in grid stensoenes.pdf? sequence=1 (27 May 2016).

2. Aver, M. R. (2011), "The Policy Sciences of Social Media", The Policy Studies Journal, Vol. 39, No. 4, pp. 709-732.

3. Black, E. (2016), "Using Social Media During a Crisis", available at: http://ababankmarketing.com/insights/using-social-media-during-a-crisis/ (16 July 2017).

4. Bukovina, J. (2016a), "Social media and capital markets. An overview", Procedia - Social and Behavioral Sciences, Vol. 220, pp. 70-78.

5. Bukovina, J. (2016b), "Social media big data and capital markets - An overview", Journal of Behavioral and Experimental Finance, Vol. 11, pp. 18-26. 
6. Central Bank of Bosnia and Herzegovina (2016), "Banks operating in Bosnia and Herzegovina", available at: http://cbbh.ba/index.php?id=7\&lang=bs (25 October 2016).

7. Chanda, R., Zaorski, S. (2013), "Social Media Usage in the Financial Services Industry: Toward a Business-Driven Compliance Approach", Journal of Taxation \& Regulation of Financial Institutions, Vol. 26, No. 5, pp. 5-20.

8. Crowe, A. (2010), "The Social Media Manifesto: A Comprehensive Review of The Impact of Social Media on Emergency Management", Journal of Business Continuity \& Emergency Planning, Vol. 5, No. 1. pp. 409-420.

9. Doman, C. (2015), "6 Big Social Media Opportunities for Financial Services (and One Gap)", available at: https://www.spredfast.com/social-marketing-blog/6big-social-media-opportunities-financial-services-and-one-gap (27 July 2016).

10. Dougherty, J. (2015), "6 Social Media "Musts" for Crisis Communication", available at: http://www.cision.com/us/2015/06/6-social-media-musts-for-crisiscommunication/ (16 July 2017).

11. Eldridge, R. (2016), "How Social Media Is Shaping Financial Services", available at: $\quad$ http://www.huffingtonpost.com/richard-eldridge/how-social-media-isshapi b 9043918.html (23 May 2016).

12. Groenfeldt, T. (2014), "Bank Clients Want Social Media Account Access", available at: http://www.forbes.com/sites/tomgroenfeldt/2014/04/25/bankclients-want-social-media-account-access-capgemini/\#24cd13c5f98a October 2016).

13. Hazarika, D., Nag, S. (2014), "How Banks can use Social Media Analytics to drive Business Advantage", publisher Cognizant, available at: https://www.cognizant.com/InsightsWhitepapers/How-Banks-Can-Use-SocialMedia-Analytics-To-Drive-Business-Advantage.pdf (20 May 2017).

14. Jin, Y., Liu, B. F., Austin, L. L., (2014), „Examining the Role of Social Media in Effective Crisis Management: The Effects of Crisis Origin, Information Form, and Source on Publics' Crisis Responses", Communication Research, Vol. 41, No. 1, pp. 74-94.

15. Joseph, K., Wintoki, M. B., Zhang, Z. (2011), "Forecasting abnormal stock returns and trading volume using investor sentiment: Evidence from online search", International Journal of Forecasting, Vol. 27, No. 4, pp. 1116-1127.

16. Karabulut, Y. (2013), "Can Facebook Predict Stock Market Activity?", available at:

https://www.ecb.europa.eu/events/pdf/conferences/140407/Karabulut_CanFac ebookPredictStockMarketActivitiy.pdf?902eb04ceaal7187b7353be87992b83a (18 May 2017).

17. King, B. (2010). Bank 2.0: How customer behavior and technology will change the future of financial services, Singapore, Marshall Cavendish Business.

18. Kumar, K. S. V., Devi, Dr. V. R. (2014), "Social Media in Financial Services - A Theoretical Perspective", Procedia Economics and Finance, Vol. 11, pp. 306-313.

19. Mucan, B., Özeltürkay. E. Y. (2014) "Social Media Creates Competitive Advantages: How Turkish Banks Use This Power? A Content Analysis of Turkish Banks through Their Webpages", Procedia - Social and Behavioral Sciences, Vol. 148, pp. 137-145.

20. Nguyen, T. H., Shirai, K., Velcin, J. (2015), "Sentiment Analysis on Social Media for Stock Movement Prediction", Expert Systems with Applications, Vol. 42, No. 24, pp. $9603-9611$. 
21. Pang, A., Hassan, N. B. B. A., Chong, A. C. Y. (2014), "Negotiating Crisis in the Social Media Environment: Evolution of Crisis Online, Gaining Credibility Offline", Corporate Communications: An International Journal, Vol. 19, No. 1, pp. 96-118.

22. Shao, D., Shao, L. P. (2012), "The Effect of Social Media on the Financial Services Industry", Journal of International Finance Studies, Vol. 12, No 4, pp. 109-114.

23. Sprenger, T. O., Sandner, P. G., Tumasjan, A., Welpe, I. M. (2014b), "News or Noise? Using Twitter to Identify and Understand Company-specific News Flow", Journal of Business Finance \& Accounting, Vol. 41, No. 7-8, pp 791-830.

24. Sprenger, T. O., Tumasjan, A., Sandner, P. G., Welpe, I. M. (2014a), "Tweets and Trades: the Information Content of Stock Microblogs", European Financial Management, Vol. 20, No, 5, pp. 926-957.

25. Sul, H. K., Dennis, A. R., Yuan, L. I. (2017), "Trading on Twitter: Using Social Media Sentiment to Predict Stock Returns", Decision Science, Vol. 48, No. 3, pp. 454-488.

26. Veenswyk, M. (2013), "Leveraging Social Media in the Banking Industry", available at: http://www.smcapture.com/documents/SMC4\%20\%20Banking\%20Social\%20Media\%200verview.pdf (27 May 2016).

27. Wendling, C., Radisch, J., Jacobzone, S. (2013), „The Use of Social Media in Risk and Crisis Communication", OECD Working Papers On Public Governance, No. 24, OECD Publishing, available at: http://dx.doi.org/10.1787/5k3v01fskp9s-en (27 July 2016).

\section{About the authors}

Mirela Mabic works at the Faculty of Economics, University of Mostar, at the Department for Business Informatics. Her research interests include Business Information Systems, Practical Application of Software and Web Technologies both in Business and in Education, Quality of Higher Education and Applied Statistics. Author can be contacted at mirela.mabic@sve-mo.ba.

Dražena Gašpar is full time professor of Database Systems and Accounting Information Systems at the Faculty of Economics, University of Mostar. Her research interests include Databases, Data Warehouse, Business Information Systems and Software Application in Business and Education. She is co-founder of a "Hera" software company in Mostar and has almost two decades of experience in developing and implementing business information systems. Author can be contacted at drazena.gaspar@sve-mo.ba.

Damir Lucović works at the Faculty of Economics, University of Mostar, as an assistant at the Department for Business Informatics. His research interests include Business Information Systems, the practical application of Software and Web Technologies both in Business and Education, e-Business, Computer Security and Networks, Cloud Computing Solutions with a lot of real-life experience in IT Management. Author can be contacted at damir.lucovic@sve-mo.ba. 